\title{
Usage period of nipah leaves nypa fructicans with salt water treatment as roofing material
}

\author{
Muhammad Zakaria Umar, ${ }^{1, *}$, Arman Faslih ${ }^{1}$, and Mazhfia Umar $^{2}$ \\ ${ }^{1}$ D3 Architecture Study Program, Vocational Education Program, Halu Oleo University, 93232 Southeast Sulawesi, Indonesia \\ ${ }^{2}$ Department of Forestry, College of Agricultural Science, Southeast Sulawesi, Indonesia
}

\begin{abstract}
At this time began to be revived the use of local materials. This is based on aesthetic and economic considerations. Therefore, researchers are encouraged to examine the knowledge of the utilization of local resources, especially nipah leaves. In Petoaha Sub District, Abeli District, Kendari City is located Kampung KB (Family Planning). Kampung KB is a former village of Bajo ethnic landed (formerly living on water). Mothers in Kampung KB are busy making roof material from nipah leaves. The leaves are taken from the palm trees that grow around Kampung KB. The phenomenon in the field that leaves soaked in sea water for 1-3 days before the roof is made. According to them that the leaves are soaked in sea water has a long lifetime compared to leaves that are not soaked in sea water. Based on their experience that watersoaked leaves have a lifetime for 3-4 years, can even reach 6-7 years when the roof thickness reaches 10 layers of palm leaves. Nipah leaves do not soak sea water has age wear for 2-3 years. This research is aimed to test the nipah leaf of marine water and nipah leaves do not soak the sea water against the period of usage. Metode plate count digunakan dalam penelitian ini. The plate count method to test the total microbial between fresh nipah leaf and nipah leaves is soaked in sea water. This study concluded that the bacteria on the nipah leaf soak the sea water is lower. Nipah leaves soaked sea water has a lifetime longer than nipah leaves do not soak sea water made roof material.
\end{abstract}

\section{Introduction}

Indonesia is an archipelagic country. Indonesia consists of 300 more ethnic groups and 500 regional languages. Indonesia is called a very rich country. The richness of Indonesian culture contains local wisdom [1]. Local wisdom has the following characteristics: spread and inheritance are oral, traditional, anonymous, pralogical, and innocent [2]. The concept of localized design no longer rests on local wisdom, as the trend for local designers to look modern is taken by glorifying and imitating foreign concepts [3]. Utilization of natural materials for building local homes in certain communities is still maintained, especially the Bajo tribe community because it is economical and available. The design of local nuances is increasingly abandoned and house building is synonymous with high costs. At this time began to be revived the use of local materials. This is based on aesthetic and economic considerations. The use of local building materials mainly for tourism buildings, restaurants, resort hotels, and others. This encourages researchers to examine the knowledge of the utilization of local resources, especially nipah leaf.

In Petoaha Sub District, Abeli District, Kendari City is located Kampung KB (Family Planning). Kampung $\mathrm{KB}$ is a former village of Bajo ethnic landed (formerly living on water). Father in the village of $\mathrm{KB}$ is busy as a fisherman. Mothers are busy searching metti-metti (bivalve shell/molusca) and making roof material from nipah leaves. The leaves are taken from the palm trees that grow around Kampung KB. The phenomenon in the field that nipah leaves soaked sea water for 1-3 days before the roof. According to them that the leaves of sea water soak have long service life compared with nipah leaf not soak sea water. Based on their experience that water-soaked leaves have a lifetime for 3-4 years, can even reach 6-7 years when the roof thickness reaches 10 layers of palm leaves. Nipah leaves do not soak sea water has age wear for 2-3 years.

Sea water consists of $3.5 \%$ salt, $55 \%$ wt Chloride Compound, Sulfate $7.7 \%$ wt, Sodium $30.6 \%$ wt, Calcium $1.2 \%$ wt, Potassium 1.1\% wt, Magnesium 3.7\% wt, and others $0.7 \%$ wt. The longer the rice straw is soaked with sea water, then the NDF content decreases. The decrease in NDF levels in straw occurs because the bonding of the stretch cell contents and NDF falls. Acid Detergent Fiber (ADF) and Neutral Detergent Fiber (NDF) drops are caused by lignocellulose and hemicellulose. High cellulose contents are caused by hemicellulosic bonds and ligandelulose bonds that are tense. Decrease in the detergent solution (NDF) results in insoluble feed. The decreased NDF content is caused by falling hemicellulose. Hemicellulose and cellulose are cell wall components and can be digested by microbes. A decrease in NDF levels causes lignin to rise and hemicellulose decreases. Thus, the breakdown of cell

\footnotetext{
* Corresponding author: muzakum.uho@gmail.com
} 
wall cellulose is indicated by decreasing NDF levels, so that the feed is easily digested by livestock [4].

Broken meatballs can be observed by the Total Plate Count method. Meatball boiled with concentration of tin ethanol leaf extract. The ethanol tin leaves have a capacity of 3.5 and $10 \%(\mathrm{w} / \mathrm{v})$. Meatballs can survive from microbiological destroyers. In the room storage temperature for 6 hours occurs broken meatballs. Control meatballs stored for 6 hours have more total slabs and are required by SNI (1.0 x 105 colonies/gram). Tin leaf extract and ethanol are boiled in meatballs. This event is able to suppress the number of plates of meatballs. Meatballs can be stored at room temperature for 6 hours. Meatballs are treated with stir. Meatballs are treated with stir. This treatment is able to extend the shelf life of meatballs for 24 hours. Meatballs are kept at room temperature for 6 hours. Meatballs added with tin ethanol leaf extract of $3.5 \%-10 \%$. This treatment results in a low TPC value. Meatballs are treated by boiling and stirring. TPC values obtained $<2.5$ x 102 colonies/grams. The TPC value is generated by an average control meatball of $3.4 \times 104$ colonies/gram. Meatballs are stored for 48 hours at room temperature and stirring can slow down damage. Meatballs are stored and given a concentration of tin ethanol leaf extract of $5 \%(\mathrm{w} / \mathrm{w})$. Ethanol tin leaf extract on meatballs was the optimum concentration [5]. Thus it can be concluded, as follows: 1) hemicellulose and cellulose down caused by sea water, so the microbe difficult to develop; 2) plate count method is used for microbial total test.

Environmental and development issues are in the hands of the United Nations Organization (UNO). Environmental degradation is addressed by UNO with continuing thinking [6]. This thinking is also growing in the field of architecture, where it must be thought of a sustainable building design and adapted to the local climate. It is necessary to design in harmony with nature to be efficient. The sustainability of future generations is contemplated by sustainable architecture. The waste of energy can be suppressed and the destruction of nature can be avoided by utilizing nature as part of the design [7]. Renewable materials can be updated and directed to vegetation such as wood, bamboo, and leaves. The vegetation material does not emit $\mathrm{CO}_{2}$ and instead absorbs $\mathrm{CO}_{2}$, so this material can be used to help reduce $\mathrm{CO}_{2}$ emissions into the atmosphere [8].

Leaves such as tepus leaves (amomum megalochelios), mareme (glochidion sp.), patat lipung (phrynium pubinerve), pinding totot (horsntedtia paludosa), salak leuweng (salacca cf. edulis), kiray (metroxylon sagu), and ijuk kawung (arenga pinnata) is used as a roof [9]. The use of materials in buildings is influenced by local geography and climate. Material selection depends on the material available around the site. Leaves (sago leaves, rumbino leaves, straw), grass (weeds), bark, and zinc are used as roofs in mountainous areas and hills. Leaf woven (sago, nipah) is used as a roof on the coastal area [10]. A kind of palm (palma) that grows in the environment of mangrove forests or in tidal areas of sea water is called nipah. Nipah grows behind mangrove forest. Nipah also grows along the river to the estuary. In the estuary there is a lot of soil sediment, so the habitat of nipah becomes fertile [11]. Nipah forest is spread in Kalimantan, Sumatra, Sulawesi, Maluku and Papua. Nipah trees are utilized by people's lives, such as roofing materials and woven house walls [12]. Thus it can be concluded that the energy-efficient roof is owned by roof material from nipah leaf, because it can be replanted and low carbon dioxide emissions. This research is aimed to test the nipah leaf of marine water and nipah leaves do not soak the sea water against the period of usage.

\section{Methodology}

This research was conducted in September 2016. This research was conducted for 3 days in Microbiology Laboratory, Biology Department, Faculty of Mathematics and Natural Sciences, Halu Oleo University, Kendari. The plate count method was used in this study. The method of plate count was chosen because to test the total microbial. Total microbes were tested between fresh nipah leaves and nipah leaves that had been soaked in seawater. Digital scales, sterile plastic containers, sterile pipettes, $\mathrm{ml}$ tubes, sterile petri, waterbath, saucer, and incubator are used as work tools. Fresh nipah leaf, nipah leaf that has been soaked seawater for three days, BFB solution, and PCA solution used as ingredients. Dilution and number of colonies are recorded. Total plate count is calculated by the formula, as follows:

with:

$$
N=\frac{\Sigma \mathrm{C}}{((1 \times n 1)+(0,1 \times n 2)) \mathrm{x}(\mathrm{d})}
$$

$\mathrm{N}$ is the number of product colonies and is expressed in colonies per $\mathrm{ml}$ or colony per gram

$\Sigma \mathrm{C}$ is the number of colonies in all calculated saucers $\mathrm{n} 1$ is the amount of cup in the first dilution calculated $\mathrm{n} 2$ is the quantity of the cup in the second calculated load

$\mathrm{d}$ is the first dilution calculated

\section{Result and Discussion}

\subsection{Preservation of Nipah Leaf In Sea Water}

The process of preserving the nipah leaves is soaked in sea water (Figure 1), as follows: 1) the nipah leaves are trimmed and tied with string. The rope is made of nipah neck skin; 2) nipah leaves soaked until drowned; 3) Nipah leaves crushed with large stones, so as not to drift away; 4) Nipah leaves are soaked for three days. Long soak based on community experience Kampung KB. Nipah leaf seaweed soaked soft texture and not easily broken, so leaves easily arranged; 5) Leaves are cleaned again with sea water. Leaves are brown and textured slick after soaking in sea water; and 6) Leaves need not wait until dry and directly processed into a roof. 


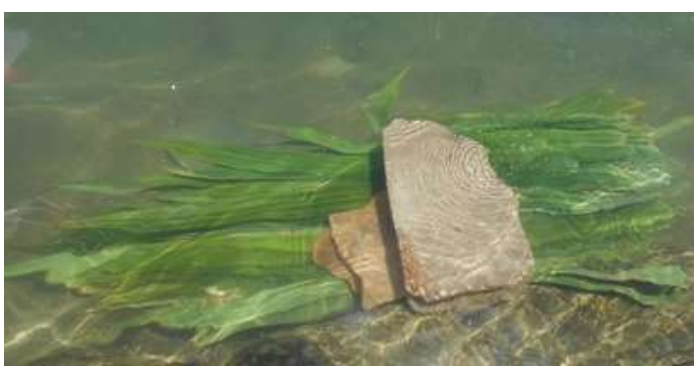

Fig. 1. Nipah leaves soaked in sea water

\subsection{Number of Bacteria in Leaf}

The result of plate count method test in table (1) explained that the number of microorganisms in fresh leaf nipah more than the number of microorganisms in nipah leaf soaked in sea water. Microorganisms found in leaves soaked in sea water and not soaked in sea water is a type of bacteria. This happens, as follows: 1) slimy sea soaked leaves. This indicates that the microorganisms that live on the nipah leaf belong to the class of bacteria. Bacteria on the nipah leaf soak the seawater amounted to little. Nipah leaf seaweed is selected bacterial growth, so the number of bacteria is less than fresh leaf nipah. Bacterial growth is influenced by the quality of sea water in the nipah leaf soaking. The temperature of the seawater around the soaking place is quite high at $33.2 \mathrm{C}$ - 34. 3C, so it can be one of the inhibitors of bacterial growth. Similarly, low dissolved oxygen (DO) values are $0.12-1.60(\mathrm{mg} / \mathrm{l})$ affects the exchange of oxygen in the water. Low oxygen exchange causes less aerobic bacteria to get oxygen supply for their growth. The salinity of seawater is quite low $24.0 \%-28.1 \%$ [13], but sea salt content can also be a limiting for bacterial development. Thus, the limiting factor of bacterial development on the nipah leaf of sea water is the relatively high sea water temperature and the low dissolved oxygen content; 2) Nipah leaves used as substrate for bacterial growth. Fresh nipah leaf has a number of bacteria more than the number of bacteria soaked sea water, so fresh nipah leaf more quickly damaged; and 3) nipah leaf soak sea water more resistant weather compared to fresh nipah leaf, so that nipah leaf soak sea water more durable than fresh leaf nipah.

Table 1. The calculation of microbial count on nipah leaf.

\begin{tabular}{|c|c|}
\hline Sample & $\begin{array}{c}\text { Number of } \\
\text { Microbes }\end{array}$ \\
\hline Fresh Nipah Leaf & $10^{5} \mathrm{cfu} / \mathrm{gram}$ \\
\hline $\begin{array}{c}\text { Nipah leaves soaked in sea water }(3 \\
\text { days) }\end{array}$ & $10^{4} \mathrm{cfu} / \mathrm{gram}$ \\
\hline
\end{tabular}

Nipah leaves soaked in sea water for long life. According to the experience of Kampung $\mathrm{KB}$ community that the roof of nipah leaf soaked sea water has a life span of 2-3 years. Based on the plate count method that the roof of nipah leaf soaked sea water more durable than not soak the sea water.

\section{Conclussion}

Based on the above description can be concluded that the nipah leaves are soaked in sea water has a longer lifetime when made a roof than the nipah leaves are not soaked in sea water. This research can be continued to investigate degradation of nipah roof depreciation against rainfall and sunlight.

Thank you to Mrs. Dr. Nur Arfa Yanti, S.Si., M.Si and Mrs. Wiwi along with family who always assist the author during the research.

\section{References}

1. I.S. Ernawi, in Local Wisdom dalam Perencanaan dan Perancangan Lingkungan Binaan (Malang: PPI Rektorat Universitas Merdeka Malang), 3 (2009)

2. J. Danandjaja, Folklor Indonesia: Ilmu Gosip, Dongeng dan Lain-lain (PT. Pustaka Utama Grafiti, Jakarta, 2008)

3. G. Pambudi, H. Asriningpurin, F. Kurniawati, J. Sains dan Teknologi Lingkungan 7, 51-65 (2015)

4. S. Oktaviani S, Under Graduate Thesis (Hasanuddin University, Makassar, 1- 2, 2008)

5. A.A. Pradana, H. Joko, K.D. Harsi, Under Graduate Thesis (Fakultas Teknologi Pertanian Bogor, Bogor, 2013)

6. A. Wahyudi, in Proseding Seminar Nasional Teknologi IV (UTY, Yogyakarta) (2008)

7. I.G.N. Antaryama, Arch. Mag. Elevent issues, 83-84 (2007)

8. T.H. Karyono, Green Architecture Pengantar Pemahaman Arsitektur Hijau Di Indonesia (PT RajaGrafindo Persada, Jakarta, 2010)

9. M. Rahayu, K. Harada, Berita Biologi Edisi Khusus: Biodiversitas Taman Nasional Gunung Halimun (HI). 71 April and 2 Agustus, 17 - 23 (2004)

10. N. Fauziah, in Simposium Nasional Teknologi Terapan (SNTT) 2 (Muhammadiyah University, Riau) A24 - A26 (2014)

11. J. Astuti, D. Yoza, R. Sulaeman, JOM. Faperta. 31 (2016)

12. L.F. Yeni, A. Hidayat, R. Marlina, J. Pendidikan Matematika dan IPA 2, 1 - 10 (2011)

13. Ira, J. Aquasains (Lampung: Universitas Lampung) p 119-123 (2012) 